\title{
Ester: Vroulike durf binne 'n manlike bestel
}

Author:
Lina Spies ${ }^{1}$
Affiliation:
'Department of Afrikaans
and Dutch, Stellenbosch
University, South Africa
Correspondence to:
Lina Spies
email:
linaspies@xsinet.co.za
Postal address:
PO Box 675, Stellenbosch
7599, South Africa
Dates:
Received: 08 Feb. 2011
Accepted: 15 Feb. 2011
Published: 07 June 2011
How to cite this article:
Spies, L., 2011, 'Ester:
Vroulike durf binne'n
manlike bestel', HTS
Teologiese Studies/
Theological Studies $67(1)$,
Art. \#1031, 10 pages. DOI:
10.4102/hts.v67i1.1031

(C) 2011. The Authors. Licensee: OpenJournals Publishing. This work is licensed under the Creative Commons Attribution License.
In this article, the Book of Esther was interpreted in a way that was clearly not intended by the author. The article aimed to specifically concentrate on the motives and character traits of the personas, as revealed by their actions. The splendour and pomp of Ahasuerus's banquet reveals his ostentatious nature that Vasthi distances herself from. In spite of the apparent humiliation of losing her position as queen, she retains her dignity as a woman. Esther, on the other hand, deals with the king's appetite for pleasure by pleasing him with her sexual wiles and sumptuous meals. The royal power that she subsequently gains enables her to save her people from extinction. The male personas are shown up by their female counterparts as being obsessed by power and status. In a fierce political struggle, Haman is brought to a fall and Mordechai, a Diaspora Jew who risks his Jewishness for his ambition, replaces him as vice-roy of Persia. God's absence in the Book of Esther is explained in that God might perhaps speak through the weak, the insignificant and the humiliated or that God withdraws in silence from the political schemes of those in power.

\section{Inleiding Verantwoording}

Ek is 'n Bybelsgevormde mens en digter. My vader het sonder om ooit ' $n$ interpretasie of 'n sedelessie daaraan te verbind soggens en saans 'n samehangende gedeelte uit die Bybel gelees. Hy het ook nie selektief gelees nie, maar by Genesis begin met die bedoeling om te lees tot by Openbaring. Hy het inderdaad ook twee keer in sy lewe die Bybel so deurgelees. Van kleins af is ek gefassineer deur die verhaal van Ester. Veral haar durf om by die die koning te gaan pleit vir die behoud van haar volk op die gevaar af dat sy haar dood tegemoet gaan as die koning haar nie binnenooi deur sy goue septer na haar uit te steek nie, het my spanning van voorlesing tot voorlesing laat styg. Oor wie die skurke en helde was, het geen twyfel bestaan nie: Die opponent van die slegte Haman was die goeie man Mordegai, die neef en pleegvader van Ester. Die magspel en die hofintriges wat so 'n belangrike deel van die verhaal uitmaak, het by my verbygegaan en na die godsdienstige betekenis van dié Bybelboek het ek nooit gevra nie. Ek was te jonk en te naïef. Die Bybel was die 'Woord van God' en geen dominee het ooit oor die menslike outeurs van die verskillende boeke gepreek nie en die gelowiges het nooit daaroor nagedink nie.

Die Bybel het sy fassinasie vir my behou, maar ek het nie'n naïewe leser gebly nie. My interpretasie van literêre tekste het my ook wetenskaplik toegerus om Bybeltekste te interpreteer, al is my gebrek aan kennis van die grondtale van die Bybel uiteraard 'n gebrek in dié toerusting. Meerdere letterkundiges, soos onder andere die Nederlandse literator Mieke Bal, hou hulle intensief besig met Bybeltekste en Bybelwetenskappers maak van literêre strategieë gebruik by hulle interpretasie van dié tekste. Die Bybel is die 'Boek agter die boeke' maar dit vind ook neerslag in die visuele kunste, beeldhouwerke en skilderye en musikale neerslag in operas, oratoriums en die kunslied. Die Bybel is so ingebed in die Westerse kultuur dat die neerslag daarvan nie weg te dink is uit die kunste nie.

Dit spreek egter vanself dat waar skrywers of digters se medium die woord is, hulle veral (indien hulle Bybels gevorm is) hulle nie kan losmaak van die Woord nie. So'n skrywer is die Israeliese Meir Shalev wat sê dat hy ongelowig is, maar blywend deur die Bybel geboei word. Sy oorvertellings van verhale uit die Hebreeuse Bybel in Nederlandse vertaling, onder die titel De bijbel nu, het vir my dié bekende verhale (waaronder die verhaal van Ester) opwindend nuut gemaak. Shalev fokus op Mordegai soos die titel van sy oorvertelling te kenne gee: De trotse jood Mordechai. Mordegai is inderdaad die manlike hooffiguur in die verhaal, maar hy en Ester vorm 'n twee-eenheid sodat die fokus op hom terselfdertyd op Ester gerig is. Deur Shalev se siening van die persoon van Mordegai kom ook die karakter van Ester onder die loep. Aanvanklik het slegs Shalev se boek my gestimuleer om Ester nuut te lees, maar ek het besef dat 'n adekwate en meersydige lees van die boek die raadpleging van ander teoretiese beskouings uit ander gesigspunte noodsaak. Waar die boek haar naam dra, is ek as leser gekonfronteer met die betekenis wat sy as hooffiguur aan vrouwees gee binne die verloop van die verhaalgebeure. My beoordeling as vroulike leser van 
die persoon en karakter van Ester het op sy beurt uitgegroei tot ' $\mathrm{n}$ feministiese perspektief toe ek haar noodwendig ook moes leer verstaan binne die patriargie waarbinne sy haarself as vrou moes verwesenlik en handhaaf. Daarby het ek tot 'n eie persoonlike insig in die godsdienstige betekenis van Ester as 'n gekanoniseerde boek van die Bybel gekom.

\section{Die genre}

In sy bydrae tot die reeks De prediking van het Oude Testament, gee J.A. Loader 'n uitstekende en indringende struktuuranalise van die boek Ester. 'n Struktuuranalise konsentreer op die opbou van 'n narratiewe teks en interpreteer slegs die aard van die personasies en die tema van die verhaal soos wat dit struktuurmatig die outeur se bedoeling kenbaar maak. Loader se uitgangspunt is om die verhaal te bespreek soos wat dit in die verskillende perikope deur die outeur opgebou word vanaf die eksposisie tot by die punt van intrige ('plot') waardeur spanning geskep word wat in die slot oplossing vind. Die 'plot' word in Ester geïnisieer deur die konflikterende intermenslike verhoudings van die personasies binne die verhaalgebeure. Ester kan tereg as 'n novelle beskou word; 'n genre wat sy oorsprong in die Antieke wêreld gehad het. I.G. Drennan (1992:351) dateer die ontstaan van die novelle as 'kort, heg gestruktureerde narratief' in 200 BCE in Miletus en Klein Asië. Ek gaan nie hier in op die ontwikkeling deur die eeue van die genre met wisselende beklemtonings van sekere kenmerke nie, maar volstaan aanvanklik met waarop Loader konsentreer: die'vormbewustheid' as essensiële kenmerk en die beklemtoning van'wat met die mens gebeur' eerder as die menslike aard. Om te vergoed vir my onkunde van Hebreeus in die oorvertel van die verhaal maak ek staat op Loader en gebruik hoofsaaklik die teks van die Nuwe Nederlandse Vertaling van 2004 wat kennelik die oorspronklike Hebreeus op die voet volg. Ek haal soms ook aan uit die Afrikaanse Vertaling van 1933 ter wille van die bekendheid van die teks, en af en toe uit die Nuwe Vertaling, al wyk dié vertaling kennelik dikwels af van die oorspronklike Hebreeus.

Die verhaal begin met 'n konvensionele openingsformule wat die enigste histories-bekende personasie aan die leser bekendstel: die Persiese koning Xerses1 wat geregeer het in die periode 485-465 BCE (Loader 1980:15-16). Met uitsondering van die historiese Xerses wat in die Bybelboek Ahasveros genoem word, is die ander personasies en die gebeure 'gefiksionaliseerde geskiedenis': 'The book of Esther, like Ruth, is historical fiction. It was written in the postexilic period, and the setting is the Persian court' (Bellis 1994:211).

\section{'n Strukturele benadering met konsentrasie op die formele elemente}

Sonder omhaal begin die outeur vertel hoe buitengewoon groot die ryk was waaroor Ahasveros geregeer het en hoe hy in sy derde regeringsjaar al die hoë funksionarisse, die hoofde van die provinsies en die leër tydens 'n langdurige fees onthaal het. Ná die eerste fees vir die adel volg 'n fees vir die inwoners van die stad Susa wat die koning as setel van sy mag gekies het. Die beskrywing van die binnehof as toneel van die feesviering wil die luister van die fees beklemtoon. Die wyn het onophoudelik gevloei maar niemand is gedwing om te drink nie.

Op die laaste dag van die fees wou die koning met sy grootste sieraad spog en beveel sy sewe persoonlike dienaars om sy mooi vrou Vasti te gaan haal met die koninklike kroon op ('getooid met de koninklijke hoofdband') om voor sy gaste te verskyn sodat hulle kon sien hoe mooi sy is. Vasti weier botweg. Die koning is woedend en vra sonder versuim die raad van sy hoogste wetsgeleerde amptenare oor wat met Vasti moet gebeur. Die raad van hierdie amptenare lui dat Vasti haar nie net wangedra het teenoor die koning nie, maar teenoor alle manlike ryksgenote wat deur hulle vrouens geminag sal word as hulle te hore kom wat sy gedoen het. 'n Bevel moet dadelik uitgevaardig en vasgelê word as 'n wet van Medië en Persië (wat nie herroep kan word nie) dat Vasti se koningskap van haar weggeneem word en dat die man tuis heer en meester moet wees.

Loader se lesing laat die karakter en die motiewe van personasies buite rekening en hy wys dus die psigologiese verklaring van Vasti se weiering af omdat die outeur volgens hom nie daarin geïnteresseerd is nie: Vasti se weiering is noodsaaklik vir die opbou van die narratief; nie die rede vir die weiering nie. Die hoogtepunt van die fees is omskep in 'n antiklimaks wat die koning se woede ontketen en 'n reeks gebeurtenisse aktiveer wat die verhaal sy verdere loop laat neem. Ahasveros het sewe howelinge gestuur om Vasti te gaan haal; nou het hy weer sewe howelinge nodig om hom raad te gee en Loader (1980:22) se slotsom lui: 'De koning is een zwakkeling die door zijn dienaren gemanipuleerd wordt.'

So'nopmerking kom welneer op interpretasievan diekarakter van Ahasveros wat uitwys dat Loader nie konsekwent net op formele aspekte konsentreer nie. Dit is wel so dat die feit dat Ahasveros besluite op ander afskuif uiters funksioneel is vir die ontwikkeling en dus vir die opbou van die verhaal. Loader se selektiewe uitwysing van karaktereienskappe van sekere personasies en die verswyging van dié van ander, verraai egter 'n sekere bevooroordeeldheid.Terwyl sy aandag op die strukturering van die verhaal gefokus is, wil hy nie ' $n$ afleiding maak oor die rede vir Vasti se weiering nie, maar spreek hy hom wel uit oor die persoon van Ahasveros waaroor hy ongetwyfeld gelyk het. Die swak, besluitlose koning volg sy paleisbeamptes se raad dat Vasti afgesit moet word en dat deur ' $n$ skoonheidswedstryd (wetlik deur die koning gereël) die mooiste deelnemer daaraan as koningin in Vasti se plek gekies moet word.

Die boek dra die naam van die hooffiguur, die mooi Joodse meisie Ester, met wie die leser eers kennismaak nadat haar pleegvader Mordegai (binne sy Joodse geslagsregister en as weggevoerde banneling) aan ons voorgestel is: 'Deze 
Mordechai was de pleegvader van Hadassa, ook Ester genoemd, die een nicht van hem was en geen vader of moeder meer had' (2:7). Ester word 'n deelnemer aan Ahasveros se skoonheidskompetisie en tot koningin in die plek van Vasti gekies. Een van die groot verdienstes van Loader se konsentrasie op die formele elemente in die verhaal is dat hy telkens verwys na die funksie van verhulling wat kan lei tot ommekeer in sy geïmpliseerde teenpool, openbaarmaking. So verbied Mordegai Ester om haar Joodse identiteit bekend te maak. Dit is 'n essensiële element in die opbou van die spanning, omdat die verswyging van Ester se Joodse identiteit nie volgehou kan word nie en aanleiding kan gee tot aktivering van die konflik wat daaraan ten grondslag lê (Loader 1980:36-37). Die laaste keer wat ons van Vasti hoor, is as Ester koningin word in haar plek en volgens Loader is dit die einde van haar funksie in die verhaal (Loader 1980:39$40)$.

Deur Mordegai se diens in die Koningspoort kom hy te hore van 'n komplot van twee van Ahasveros se lyfwagte, Bigtan en Teres, om hom te vermoor. Mordegai deel dit aan Ester mee en sy dra dit oor aan Ahasveros. Die moordaanslag word voorkom en die verhaal word opgeteken in die kronieke van die Persiese ryk. Getrou aan sy formele lees van die teks beweer Loader: 'De redenen voor het smeden van hun komplot blijven buiten de gezichtskring - opnieuw in overeenstemming met de techniek van die auteur die geen belang stelt in niet-functionele beweegreden' (Loader 1980:45). Wat wel funksioneel is vir die toekomstige ontwikkeling van die verhaal, is die optekening van die episode in die Persiese geskiedskrywing waarop Loader (1980:46) tereg wys.

Die derde hoofstuk van die boek word ingelui deur die mededeling dat 'ná verloop van tyd' koning Ahasveros 'n sekere Haman van wie ons intussen nog niks verneem het nie, verhef tot 'tweede in rang onder de koning zonder dat hij iets gedaan heeft waarmee hij deze eer zou verdienen' (Loader 1980:46). Ook hier wyk Loader af van sy benaderingswyse, want hy keur in geval van die komplot van Bigtan en Teres dit goed dat die outeur hulle beweegredes verswyg, maar hier keur hy Ahasveros se verswyging van sy beweegredes vir die bevordering van Haman af. Loader se kontrastering van die uitbly van die beloning aan Mordegai vir sy weldaad (2:22-23) en die onverdiende 'beloning' van Haman (sy bevordering tot onderkoning in 3:1) kontrasteer indirek die 'slegte Haman' met die 'goeie Mordegai'. Hierdie teenstelling kan Loader egter op hierdie tydstip nog nie uit sy formele lesing van die teks motiveer nie. Die verhoging van Haman is egter uiters funksioneel omdat dit die direkte oorsaak is vir die konflik tussen hom en Mordegai. As almal in die paleispoort op bevel van Ahasveros voor Haman buig, behalwe Mordegai, lê dit voor die hand dat dit Haman se uiterste misnoeë sal wek.

Haman is aanvanklik onbewus daarvan dat Mordegai nie voor hom buig nie totdat Ahasveros se hoë amptenare hom daarop attent maak. Intussen het Mordegai aan hulle gesê dat hy 'n Jood is en hulle wil nou sien of Haman sy miskenning as onderkoning deur 'n Jood sal tolereer. Loader (1980:50) wys op die implikasie: Jode buig nie voor heidene nie. Dit lees hy in die teks in, want dit word nie eksplisiet vermeld nie. Haman is woedend en besluit om Mordegai uit die weg te ruim, maar toe hy verneem dat Mordegai 'n Jood is, sweer hy wraak op die hele Joodse volk. Hy vra Ahasveros se toestemming om 'n bevelskrif uit te vaardig om 'n volk wat versprei in sy ryk leef met hulle eie wette en hulle nie hou aan die wette van die koning nie, te laat uitroei.

As Haman volmag kry om met die Jode te doen wat hy wil, word hy binne die konteks van Jodehaters geïdentifiseer as 'Haman, de zoon van Hammedata, de nakomeling van Agag, de vijand van de Joden' (3:1). Loader (1980:58) wys op die belangrikheid van Haman se agagitiese afkoms omdat dit uitdruklik in verband gebring word met die feit dat hy die 'teenstander van die Jode' is, want hy stam af van die 'oervyand van Israel'. So word die konflik Mordegai-Haman binne die perspektief van die geskiedenis geplaas.

Dit kan so 'n knap leser as Loader nie ontgaan wat die gevolge daarvan is dat Mordegai onverwags openlik met sy volksverband vorendag kom nie, maar hy vind 'n verskoning vir Mordegai:

Mordechai is de oorzaak van het gevaar voor alle Joden en Haman maakt er een realiteit van. Waar Mordechai's beweegreden niet louter trots, maar zijn Jood-zijn is (zonder uitwerking van de religieuze ondertoon daarvan), wordt Haman door trotse hoogmoed gedreven.

(Loader 1980:51)

Dan lê Loader weer die klem op die struktuur van die verhaal: Mordegai se afkoms moet bekend word om die krisis te laat ontstaan, Ester s'n moet verborge bly om die krisis op te los (Loader 1980:54).

Op Ester rus die verantwoordelikheid om na die koning te gaan in opdrag van Mordegai en vir haar en haar volk se lewens te pleit. Dit eis van haar meervoudige optredes. Eerstens moet sy op lewensgevaar af die koning se teenwoordigheid betree, omdat hy haar nie ontbied het nie. Ahasveros kom egter weer so sterk onder die indruk van Ester se skoonheid dat hy haar ontvang en onmiddellik (getrou aan sy impulsiewe aard) beloof dat sy kan vra wat sy wil, tot die helfte van sy koninkryk, dit sal haar geskenk word. Bewus van die ondeurdagtheid van die koning se belofte en van sy liefde vir eet en drink, nooi sy hom en Haman na twee agtereenvolgende feestelike maaltye by haar uit.

Voor die tweede maaltyd volg eers die koning se slapelose nag waarin hy vra dat daar vir hom uit die kronieke van sy ryk voorgelees moet word. Soos te verwagte word daar stilgestaan by hoe Mordegai die aanslag op Ahasveros se lewe afgeweer het en dat hy nooit daarvoor vergoed is nie. Op dié kritieke oomblik en onwaarskynlike nagtelike uur staan Haman in die binnehof, kennelik omdat hy wil sorg dat Mordegai so gou as moontlik opgehang moet word sodat daar 'n einde kan kom aan sy irritasie. Maar iets totaal anders gebeur. Ahasveros vra hom wat moet gebeur met die 
man aan wie die koning eer wil bewys en die ydele Haman dink natuurlik dat hy die man is: Die vereerde moet, in ' $n$ kleed wat die koning reeds gedra het, op 'n perd waarop die koning reeds gery het, oor die stadsplein gelei word deur 'n adellike ryksgenoot wat voor hom uitroep: 'Dit val elkeen te beurt aan wie die koning eer wil bewys!' (6:9). Tot sy vanselfsprekende ontsteltenis kry Haman die opdrag om die eerbetoning presies soos hy dit voorgestel het aan die 'Jood' Mordegai te bewys. Die koning dra dus op dié tydstip kennis van Mordegai se volksverband.

Haman het geen keuse nie; hy voer die koning se opdrag uit (6:11) en keer daarna treurig na sy huis terug. Tuis het sy vrou en vriende wat so gereed was om hom aan te raai om Mordegai te laat ophang, vir hom geen trooswoord nie. Hulle voorspel inteendeel dat waar hy nou reeds teen Mordegai verloor het, die oorwinnig van Mordegai as Jood en van die Joodse volk vasstaan. Waar Ahasveros nou weet dat hy sy lewe aan 'n Jood te danke het en nie-Jode oortuig geraak het dat die Jode sal oorwin, het Loader nie ongelyk nie dat die werking van ' $n$ verborge ordende mag veronderstel kan word (Loader 1980:99). Die woorde van Haman se vrou en vriende dat hy ongetwyfeld die onderspit teen Mordegai sal delf, is nog nie nie koud nie of die koning se dienaars arriveer om Haman onmiddellik te kom haal vir die tweede feesmaal by Ester.

Tydens die tweede feesmaal kom Ester vorendag met die dood wat haar en haar mense in die gesig staar deur 'n beplande volksmoord. As sy die vinger wys na Haman wat saam met hulle aan tafel is as die booswig wat vir die plan verantwoordelik is, begewe die koning hom woedend na die paleistuin. By sy terugkeer kry hy die indruk dat Haman wat smekend by Ester op die rusbank neergeval het, besig is om haar aan te rand. Die verdagte tafereel laat sy woede opnuut ontvlam en as hy van die eunug aan diens hoor van die galg wat Haman intussen vir Mordegai opgerig het, laat hy Haman daaraan ophang.

Inderdaad kry Haman hier die straf wat hy verdien. Hy was inderdaad soos Meir Shalev tereg sê nie van die begin af 'n Jodehater nie; hy het dit deur Mordegai se oneerbiedige optrede teenoor hom geword (Shalev 1995:118). Ook was hy nie sonder meer sleg in vergelyking met Mordegai nie wie se twyfelagtige eerbaarheid Shalev ook uitwys. Hy dra egter sy misnoeë oor een Jood wat tot 'n verterende haat ontwikkel, op die hele Joodse volk oor; 'n psigologiese geneigdheid wat algemeen-menslik is. Op briljante wyse toon Loader verder aan in watter opsigte Ester as Wysheidsboek beskou kan word deur die karaktereienskappe wat veral Haman as persoon kenmerk.

Eers openbaar Haman, wanneer hy vir die tweede feesmaal by Ester uitgenooi is, sy oormoedige selfvertroue as hy teenoor sy vrou en vriende spog met sy geweldige rykdom, sy groot aantal seuns, sy hoë posisie en sy tweede uitnodiging na Ester. Loader (1980:85) wys op hierdie grootdoenerigheid as ' $n$ tipiese menslike kenmerk wat in die Wysheidsliteratuur onder die loep kom: 'Haman is het type van de overmoedige: overmoed en vals zelfvertrouwen zijn kenmerken van een dwaas.' Loader noem verskillende bewysplase uit Spreuke waaronder die volgende twee: 'Die weg van 'n dwaas is reg in sy eie oë, maar die wyse luister na raad' (Spr 12:15); 'Die wyse vrees en wyk af van die kwaad, maar die dwaas bruis op en is vol selfvertroue' (Spr 14:16). Ook die vernedering van Haman as hy eer moet bewys aan sy aartsvyand Mordegai, kom letterlik ooreen met wat in Spreuke 25:6-7 staan:

Pronk nie voor die koning nie, en staan nie op die plek van die grotes nie. Want dit is beter dat vir jou gesê word: 'Kom op hierheen!' - as dat jy verneder word voor 'n edele wat jou oë gesien het.

Wanneer Haman gehang word aan die galg wat hy vir Mordegai opgerig het, gaan Spreuke 26:27 letterlik in vervulling: 'Wie 'n kuil grawe, sal daarin val; en hy wat 'n klip rol, dit sal na hom terugkom'.

Met Haman uit die weg geruim en Mordegai in sy posisie is die spanning verswak, maar nog nie opgelos nie. Die oplossing kom eers twee maande later as Ester Ahasveros aan sy voete smeek om haar en haar volk se lewe. Sy en Mordegai kry die reg om 'n bevelskrif in belang van die Jode op sy gesag uit te vaardig. Daarvolgens kon die Jode hulleself verdedig as hulle op grond van Haman se dekreet op die dertiende van die twaalfde maand, Adar, aangeval word.

Vir die Jode het 'n tyd van lig en vreugde en feesviering aangebreek. Oral het mense hulle by die Jode aangesluit waarvoor die rede slegs die bekendheid en faam van Mordegai, weens sy hoë posisie aan die hof, kon gewees het (Loader 1980:124). Met hulle geledere gesluit en versterk, is in Susa alleen vyfhonderd man gedood waaronder die tien seuns van Haman wat die outeur (soos Loader aantoon) nie nalaat om by die naam te noem nie. Daarmee wil die outeur duidelik maak dat met dié seuns se dood die hele geslag van die Agagiete tot 'n einde gekom het (Loader 1980:125). Die stryd is besleg maar die koning vra aan Ester of sy nog iets begeer en sy spreek twee begeertes uit: dat die stryd vir 'n tweede dag in Susa voortgesit kan word en dat die lyke van die tien seuns van Haman aan galge opgehang moet word. Hierdie versoek lei tot die dood van nog driehonderd man in Susa en tot die skending van die lyke van Haman se seuns.

Die meeste kommentatore beskou Ester se laaste versoek as moreel minderwaardig en ander probeer om dit te verontskuldig. Dit is vir Loader (wat hom by sy formele benadering hou) 'n poging om veronderstellinge die teks binne te dra wat daaraan vreemd is en om die literêre funksie van die versoek te misken (Loader 1980:18). Hy vind die motivering van nog 'n dag se slagting in Susa daarin dat die Poerimfees wat as herdenking van die Joodse oorwinninng deur Ester en Mordegai ingestel is, op twee agtereenvolgende dae, naamlik op 14 en 15 Adar, gevier word. Die geskiedenis van die Poerimfees kan nie presies gerekonstrueer word nie, maar Loader (1980:143) vind dit tereg geen beletsel nie, omdat die verhaal self die motivering gee vir vas gevolg deur feesviering omdat droefheid en rou omgekeer is in vreugde.

Daar word ook uitdruklik gestel dat die Poerim verpligtend gemaak word deur 'n tweede skrywe van Ester en Mordegai. 
As die kort tiende hoofstuk wat die verhaal afsluit, die klem lê op die mag van Ahasveros en die hoë posisie van Mordegai, ontstaan die vraag of Ester nou uit die teks verdwyn? Daarop antwoord Loader (1980):

Het op de voorgrond treden van Mordechai voorkomt dat Esther bij de lezer voorrang krijgt, omdat zij in de vorige perikoop Mordechai's brief bevestigde en dus meer macht leek te hebben dan haar voogd ... In diepste zin doen beide voorspraak voor hun volk, zoals eertijds Mozes dat deed.

(Loader 1980:145)

J.A. Loader gee 'n helder uiteensetting van hoe die boek Ester opgebou is deur die verhaal oor te vertel met konsentrasie op die formele aspekte. Hy weerhou hom van wat die teks impliseer oor die personae in die verhaal soos wat hulle aard en karakter blyk uit hulle dade en woorde. Hierin is hy nie altyd konsekwent nie soos wat ek reeds in my bespreking van sy weergawe van die teks laat blyk het. Hy interpreteer wel eksplisiet 'n personasie se karakter as sy/haar optredes of uitsprake uitdrukkings is van wat die Wysheidsboeke van die $\mathrm{Ou}$ Testament daaroor leer.

Verder lees Loader Ester binne die konteks van die Ou Testament en lig hy parallelle tussen Ester en hoofpersone in ander $\mathrm{Ou}$ Testamentiese verhale uit. Sy word as redder van haar mense 'n prototipe van Moses, Josef en Daniël. Aldrie hierdie Jode styg in die Diaspora aan die hof van 'n koning tot ' $n$ belangrike posisie van waaruit hulle die mag kry om hulle eie mense te bevry. Dit blyk dat daar vir Mordegai nie 'n duidelike parallel in die $\mathrm{Ou}$ Testament te vinde is nie, tensy hy, in sy onlosmaaklike verbintenis met Ester, aan haar gelykgestel word as 'n reddersfiguur. In eerste instansie is Loader se lees van Ester egter afgestem op hoe daar oor dié boek in 'n Christelike gemeente gepreek kan word. Sy boek is immers deel van 'n reeks De prediking van het Oude Testament en dit spreek dus vanself dat hy 'n lyn vanaf Ester moet deurtrek na die Nuwe Testament. Dit lei onvermydelik daartoe dat hy die boek deurentyd lees deur die bril van die interpretasie waarby hy moet uitkom ter wille van Nuwe Testamentiese teoloë en predikante wat verplig is tot die gepaste prediking in 'n Christelike gemeente

\section{Vroulike waardigheid} Vasti: 'n Bybelse feminis

Die episode in die boek Ester wat die handelingsverloop aktiveer, is die antiklimaks van koning Ahasveros se imponerende fees as hy met sy grootste sieraad, sy mooi vrou koningin Vasti, wil spog en sy weier om haar verskyning te maak. Loader (1980:24) interpreteer Vasti se weiering as ongehoorsaamheid aan haar man wat nie in staat is om haar te beheer nie. In sy lesing van Ester, eweneens soos Loader in die oorspronklike Hebreeus en met die oog op die eerste Joodse lesers as ontvangers van die teks, sê David Clines (1990:31) in ooreenstemming met Loader dat die Persiese koning as 'n 'monarch of absolute power', 'n 'showy entertainer' en ' $n$ 'sovereign in masterful control' net op die huishoudelike front nie sy mag kan laat geld nie. Sy onmag om sy vrou se gehoorsaamheid af te dwing, sou van hom 'n gek gemaak het in die oë van die aanvanklike Joodse lesers en Vasti se rol in die boek sou daarmee uitgespeel gewees het.

Binne die hedendaagse konteks en met gebruikmaking van hedendaagse leesstrategieë is om, in die woorde van Clines (1990:31), 'van links na regs te lees' en op dié manier kan onder andere Vasti in 'n ander lig te staan kom. Ons kan dus anders lees as met die oogmerk om die bedoeling van die outeur van die oorspronklike Hebreeuse teks te agterhaal as die enigste moontlike en geldige betekenis daarvan. Soos reeds geblyk het uit my weergawe van Loader se lesing, erken hy indirek teen sy formalistiese benadering in dat Vasti nie uit die teks uitgeskryf is nie. So kan dit nie sy aandag ontgaan nie dat wanneer Ester ongevraagd na die koning gaan, Vasti se afsetting in herinnering geroep en die risiko wat Ester loop, geïntensiveer word. Albei vroue trotseer immers op verskillende maniere en met verskillende bedoelings die koning se mag.

Ahasveros weet dat daar teen Vasti opgetree moet word, maar hy is 'n swakkeling wat nie self besluite kan neem nie (daaroor stem alle kommentatore saam) en hy vra sy sewe mees vertroude 'raadshere' wat met Vasti moet gebeur. Sowel in die $\mathrm{Ou}$ Afrikaanse as in die Nuwe Nederlandse Vertaling verwoord dié hooggeplaastes hulle raad aan die koning deur te sê dat hy Vasti haar 'koninklike waardigheid moet ontneem en aan iemand moet gee wat beter is as sy'. Wat in der waarheid met Vasti gebeur, is dat sy haar menslike en haar vroulike waardigheid behou deur te weier om haar as seksobjek aan 'n groep dronk mans te vertoon. Vasti self gee geen verklaring waarom sy nie aan Ahasveros se versoek voldoen nie. Sy weet dat haar menslike waarde alleen vir die koning en sy manlike raadgewers aan haar liggaam verbonde is, daarom eien sy haar menslike reg vir haar toe om te weier:

Since she is regarded by the male as significant only for her body, and since she depends on no argument or principle or precedent to excuse her noncompliance to his sexist demands, but simply asserts her human right to say no, we find ourselves hailing her as the first (perhaps the only) radical feminist in the Bible.

(Clines 1990:32)

Die koning en sy raadshere mislei hulle self as hulle glo dat hulle Vasti straf as hulle wetlik laat bepaal dat sy nie weer onder die oë van die koning mag kom nie. Vasti egter het alreeds laat blyk dat sy nie 'n lus vir die koning se oë wil wees nie en die raadshere vervul in der waarheid haar grootste begeerte: om nooit weer voor hom te verskyn nie (Clines 1990:41).

\section{Ester: Van pion tot vorstin}

Wanneer Ahasveros in sy nugterheid weer aan Vasti dink en moontlik berou het omdat hy haar deur se eie toedoen verloor het, is sy kamerdienaars onmiddellik weer by met raad. Hulle stel 'n skoonheidswedstryd voor: 'Er zouden voor de koning mooie jonge meisjes gezocht moeten worden, meisjes die nog maagd zijn' (2:3). Hulle voorstel lui verder dat die koning in al sy provinsies gevolmagtigdes moet aanstel om die meisies te gaan soek en in Susa bymekaar moet bring om in die vroueverblyf onder toesig van Hegai, die eunug, die 
koning se haremwagter, geplaas te word. Ná 'n langdurige skoonheidsbehandeling kry elke meisie dan 'n beurt om vir 'n nag na die koning te gaan. Die meisie wat die koning die meeste geval, moet dan koningin word in Vasti se plek. Die koning stem in en die raad word ten uitvoer gebring.

Op dié tydstip maak die leser kennis met die Jood Mordegai, die Benjaminiet, as balling deur Nebukadnésar weggevoer, wat in Susa woon. Hy is ook die pleegvader van sy niggie Hadassa, ook genaamd Ester, wat hy na haar ouers se dood as dogter aangeneem het. Deur die vermelding van sy genealogie en sy sorg en opvoeding vir sy niggie word Mordegai aan ons voorgestel as 'n eerbiedwaardige man. Die teks meld dat Ester haar ook in Hegai se harem bevind as kandidaat om koningin te word, maar nie oor hoe sy daar gekom het nie. Lillian R. Klein (1995) wys daarop dat Mordegai niks doen om Ester se deelname aan 'n on-Joodse skoonheidswedstryd te verhoed nie:

Mordechai, we note, does not direct Esther to enter the beauty contest and remains uninvolved in this un-Jewish behavior. Nevertheless, he does nothing to interfere with Esther entering into a situation foreign to Jews or her potential loss of shame.

(Klein 1995:157)

'Shame' moet hier nie verstaan word as 'skande' of 'skaamte' nie maar as 'skaamtegevoel' wat die funksie vervul van 'n beskermende grens wat 'n vrou (en 'n man!) se eer beskerm en in so 'n harem oorskry kan word.

Mens moet wel die toegewing maak dat dit skaars moontlik was vir onderdane om hulle te verset teen diegene wat ' $n$ absolute vors se bevele uitvoer (vgl. Clines 1990:45). Waar ek na my beskouing oor Vasti as die sterk vrou en die feminis, nou die karakter van haar opvolger Ester onder die loep wil neem, kan ek dit nie los van 'n bespreking van Mordegai se karakter en handelinge doen nie, omdat Ester deurgaans by hom betrokke is en hy haar in haar doen en late noodwendig moet beïnvloed. Daar is 'n gelykgeskakeldhied tussen hulle wat Loader (1980:73) as volg verwoord: 'De verhouding tussen Esther en Mordechai is tot in de fijnste bijzonderheden evenwichtig uitgewerkt ... Wie is de hoofdfiguur? Het is niet mogelijk tussen Esther en Mordechai te kiezen!'

In plaas van die beskouing van Mordegai as die 'goeie Jood' sien Meir Shalev hom deurgaans as 'n trotse en tipiese Diaspora-Jood. Tydens dielangdurige skoonheidbehandeling wat die aanspraakmakers op die troon van koningin ondergaan, wandel Mordegai langs die voorhof van die vroueverblyf om te wete te kom hoe dit met Ester gaan en wat van haar sal word. Shalev (1995:114) skryf die feit dat Mordegai voortdurend daar rondhang toe aan spanning of Ester koningin sal word eerder as aan sy besorgdheid oor haar (2:11). Elke pretendent word ses maande met mirreolie en daarna ses maande met balsem behandel. Die presiese datering van Ester se nag met die koning, soos van die meeste belangrike gebeurtenisse in die teks, maak meerdere dinge duidelik: Meisies het om die beurt die skoonheidsbehandeling ondergaan en nie tegelykertyd nie. Dit het vier jaar na die afsetting van Vasti geduur voordat Ester aan die beurt gekom het (Loader 1980:39). Verder wys dit op die lang verblyf van 'n meisie in die harem wat impliseer dat sy aan uitgerekte spanning oor wat haar uiteinde sal wees, onderwerp word. Ook vir Mordegai is die spanning dus lank uitgerek en moes hy vele wandelinge in die omgewing van die vroueverblyf onderneem het!

Wat dit beteken om 'na die koning in te gaan', spreek vanself, naamlik dat elke meisie wat in die aand na die koning gaan met hom seksuele verkeer het. Mirre en balsem is albei twee welriekende soorte hars en dat juis dít die kosmetiese behandeling uitmaak, impliseer dat 'n maagd as 'n bedmaat vir die koning voorberei word. Behalwe 'n stimulant vir die man se seksuele drif, het Clines (1990:42) nie ongelyk as hy beweer dat die versekering dat die koning se bedmaat lekker sal ruik, suggereer dat 'daar iets afstootliks kleef aan 'n meisie in haar natuurlike staat' nie. As die meisie, van haar maagdelikheid ontneem deur ' $n$ wellustige koning, in die oggend terugkom na die vroueverblyf sonder dat sy die spesiale guns van die koning gewen het, gaan sy vir goed na die tweede vrouehuis as byvrou en kom nooit weer by die koning nie, tensy hy haar spesiaal ontbied.

Die spesiale guns wat die meisie van die koning kan ontvang, berus op niks anders as die seksuele genot wat sy hom verskaf nie. Gedwonge seksuele ervaring is ten diepste niks ander as verkragting nie. Dit word in die boek Ester as 'n natuurlike gebeurtenis voorgestel:

The virgins with whom the king forcibly had sexual intercourse are categorized according to the euphemistic adjective 'delight'; hence the girl that 'delighted' the king the most was asked to return.

(Nadar 2006:89)

Die suggestie dat die koning slegs 'n meisie wat hom seksueel plesier verskaf het, weer na hom sal ontbied, word vermy in albei Afrikaanse Bybelvertalings; dit sal gebeur indien die koning 'behae in haar gevind het' of as hy 'van haar gehou het' lui dit respektiewelik in die 1933- en die 1983-vertaling (2:14). Die Nuwe Nederlandse Vertaling skram nie weg van waarom die koning 'n meisie weer na hom toe sal laat kom of nie sal laat kom nie: 'Ze ging niet opnieuw naar die koning, tenzij hij haar begeerde en zij persoonlijk bij hem werd ontboden' (outeur se kursivering). Die moontlikheid dat Ester ook tot byvrou gedegradeer kan word, verhoog die spanning.

Ester gaan egter met 'nuchtere berekening' (Loader 1980:38) te werk as dit haar beurt is. Sy is reeds Hegai se gunsteling en vra hom wat sy moet 'saamneem'. Wat saamgeneem moet word, is onduidelik. Clines (1990:42) maak die afleiding dat dit kunsmatige mooimaakgoed ('artificial beauty aids') moes gewees het. Die effek van Hegai se raad blyk wel uit die teks wat impliseer dat sy besonder mooi moes gelyk het vir haar nagtelike 'oudiënsie' met die koning, want oor wie haar gesien het onderweg na hom word gesê: 'En allen die Ester zagen, keken vol bewondering naar haar' (2:15). Ester is dus slim genoeg om op haar natuurlike skoonheid te vertrou. Geen wonder dat sy Ahaveros se 'bewondering' wek en dat hy vir haar meer 'liefde' voel as vir 'alle ander vroue' nie en haar koningin maak in Vasti se plek (2:17). Maar die liefde 
wat ná een nag lei tot die impulsiewe koning se besluit dat Ester die aangewese koningin is, kan beswaarlik deur iets anders as seksuele ervaring opgewek gewees het.

Manlike mag beheers die seksuele bestel in die Persiese ryk: die man is heer en meester in sy huis aan wie die vrou onderdanig moet wees. Dit is ook onderliggend aan die portrettering van Ester. Sy is anders as Vasti 'n 'tradisionele' vrou en geen radikale feminis nie; 'n 'skoonheidskoningin' en 'n 'charmer' (Clines 1990:42). Die eerste daad van Ester as koningin is dat sy aan die koning die komplot van twee van sy lyfwagte om hom te vermoor, bekend maak. Die tydstip waarop die twee lyfwagte hulle komplot smee, verbind die outeur met Mordegai se aanwesigheid in die Koningspoort; hy moet immers sorg dat Ester daarvan kennis neem:

Toen Mordechai dus in de Koningspoort zat, gebeurde het dat twee eunuchen die de koning als lijfwacht dienden, Bigtan en Teres, uit verbittering een plan beraamden om koning Ahasveros om het leven te brengen.

Die grond van hulle verbittering kan niks anders wees as hulle ontmanning nie. In sy beheer van die seksuele bestel in sy ryk staan nie net die vrou nie maar ook die man onder die mag van die koning. Bigtan en Teres word opgehang. Onderliggend aan hierdie gebeurtenis is daar 'n subtiele teenstelling tussen vroulike skoonheid (Ester) en manlike geskondenheid (Bigtan en Teres) en ironies genoeg word beide die vrou en die man se menswees gereduseer tot hulle seksualiteit.

Die eintlike spanning in die verhaal word ontketen in die derde hoofstuk wanneer Mordegai nie voor Haman buig nie en hy daarop attent gemaak word. Meir Shalev (1995:117) wat 'n kritiese kyk op Mordegai het, wys op sy 'selectieve joodse eergevoel'. Eers is hy bereid om teen alle Joodse beginsels in sy niggie uit te lewer aan Ahasveros se harem en nou deins hy nie daarvan terug om deur sy onbuigsame vroomheid sy hele volk in die Persiese ryk in doodsgevaar te stel nie (Shalev 1995:116). Mordegai provokeer Haman in die volle wete dat Haman die openbare aantasting van sy waardigheid en die verontagsaming van die koninklike bevel nie ongemerk by hom sal laat verbygaan nie. Ook sorg hy daarvoor dat Haman te hore kom tot watter etniese minderheid hy behoort (die rede vir die openbare demonstrasie van sy vroomheid). Shalev (1995) besluit:

Haman was niet van het begin af een jodenhater. Het opzettelijk provacatieve gedrag van Mordechai leidde tot Haman's wens 'dat men alle joden zou verdelgen, van de jonge tot de oude toe, de kleine kinderen en de vrouwen'.

(Shalev 1995:118)

Hoofstuk 4 neem 'n aanvang met Mordegai se roubeklag wanneer hy met geskeurde klere en as op sy hoof deur die stad loop terwyl hy weeklaag. Waar Shalev Mordegai sien as 'n Diaspora-Jood wat bereid is tot grootlikse assimilasie met die oog op eie gewin, spreek dit vanself dat hy nie die mening huldig dat Mordegai treur oor die ellende waarin hy die Jode gedompel het nie. Wanneer Ester verneem wat Mordegai doen, stuur sy aanvanklik vir hom skoon klere om aan te trek wat nogal vreemd voorkom, omdat sy as Jodin die tipiese Joodse rouritueel behoort te herken vir wat dit is. Haar persoonlike dienaar Hatag word die tussenpersoon deur wie Ester en Mordegai met mekaar kommunikeer.

Mordegai oorhandig aan Hatag 'n afskrif van die dekreet om aan Ester te toon, haar in te lig en haar te beveel (4:8). Loader (1980:67) wys op dié drie infinitiewe in die oorspronklike Hebreeus waarvan die drie ander adjektiewe afhanklik is in die formulering van Mordegai se opdrag aan Ester: Sy moet na die koning gaan, hom om genade smeek en vir haar volk voorspraak doen. Ester het nog deurentyd haar neef se gesag oor haar aanvaar deur onder andere haar Joodse afkoms tydens die skoonheidswedstryd te verswyg (2:10) en ook ná haar verkiesing as koningin (2:20). Nou ontvang sy van hom nie 'n versoek nie, maar 'n bevel. Deur Hatag herinner Ester Mordegai egter dié keer aan die lewensgevaarlike risiko wat sy sal loop, deur sy opdrag uit te voer; die doodstraf wag op dié een wat sonder dat hy of sy ontbied is na die koning gaan: 'Wat mijzelf betreft, ik ben nu al in geen dertig dagen bij de koning ontboden' (4:11). Die spanning word op dié wyse verhoog en beklemtoon terselfdertyd die koning se wispelturigheid: Die leser ken Ahaveros op dié tydstip goed genoeg om te weet dat in 'n periode wat langer as dertig dae kon gewees het, die koning, sonder dat hy Ester begeer het, nie kuis sou geleef het nie.

Mordegai se antwoord aan Ester lui dat sy haar nie moet verbeel dat sy in die paleis sal ontkom aan die lot van die Jode nie. As sy nie haar mond oopmaak en praat as die oomblik daar is nie, sal daar wel vanuit ' $n$ ander oord redding vir die Jode kom, maar sy en haar vader se familie sal omkom. En Mordegai voeg die beroemde uitspraak daaraan toe: 'Wie weet of jy nie met die oog op 'n tyd soos hierdie tot die koninklike waardigheid geraak het nie?' (4:14). Vir Klein (1995:163) spreek hierdie opdrag van 'n sekere harteloosheid by Mordegai of dalk van 'n geringskatting van vroue. Dis wel ongetwyfeld so dat Ester eerder as hyself sukses sal hê deur die koning te nader, maar dit regverdig nie die dreigende toon wat hy aanslaan en boonop verbind aan sy sekerheid dat, sou sy weier, daar van êrens anders redding vir die Jode sal kom nie. Ester weet dat dit holle woorde is en dat die redding van die Jode net sal kom as sy op lewensgevaar af by die koning vir hulle sal intree. Daarom vra sy Mordegai om saam met die Jode vir drie dae te vas, terwyl sy dieselfde saam met haar diensmeisies sal doen voordat sy haar lewe gaan waag deur ongenooid die koning se teenwoordigheid te betree.

Ester is nie ' $n$ passiewe personasie nie, al is sy as vrou in die ondergeskikte posisie in die verskillende verhoudings waarin sy teenoor 'n man te staan kom. Sy het geweet hoe om die guns van die haremwagter Hegai te wen. Mordegai het haar as sy dogter aangeneem en op grond daarvan was sy hom gehoorsaam. Wanneer sy die skade moet herstel wat Mordegai aangerig het deur uit te blaker dat hy as Jood nie voor Haman buig nie, strek haar gehoorsaamheid om haar volksverband te verswyg, haar tot voordeel. Sy kan met vroulike waardigheid optree en hoef haar nie as Jodin voor 
Ahasveros te verneder nie, anders as wat Mordegai met sy openbare roubeklag gedoen het. Ester weet glashelder oor watter gawes sy as koningin beskik: haar skoonheid en haar kookkuns. Albei gawes kan sy tot haar voordeel gebruik as sy oorgaan tot aksie. Sy huiwer nie om die koning so sterk as moontlik met haar skoonheid te probeer beïndruk as sy op doodsgevaar af na hom toe gaan nie. 'She herself falls in with the prevailing sexual politics when she does not hesitate to use her female charm as a bargaining counter' (Clines 1990:42). Sy gaan staan in haar koninklike gewaad in die binnehof regoor die troonsaal sodat Ahasveros haar kan raaksien en word nie in haar verwagting teleurgestel nie. Ahasveros voel onmiddellik so tot haar aangetrokke dat hy sy goue septer na haar uitsteek.

Die koning se aanbod dat hy haar alles sal gee (tot die helfte van sy koninkryk) verstaan Ester vir wat dit is: 'n hiperboliese uitspraak van sy vrygewigheid teenoor haar. Sy neem dit nie letterlik op nie, maar besef dat sy die geleentheid moet skep om met die oog op sukses te vra wat sy wil. Ester gaan met skerpsinnige berekendheid te werk en nooi die koning en Haman uit na 'n maaltyd wat sy reeds voorberei het. Sy maak weer eens haar eintlike versoek nie bekend nie maar vra dat die koning en Haman die volgende dag weer by haar ' $n$ maaltyd moet kom geniet waartydens sy dan haar hartsbegeerte openbaar sal maak. Hierdie keer verwoord sy haar uitnodiging so dat dit lyk of sy daarmee, as die koning se onderdanige vrou, eintlik aan sy wens om by haar te kom eet, voldoen:

'Wat ik wil vragen, wat ik wens' ... antwoorde Ester, 'als de koning mij goedgezind is en als de koning genegen is mij te geven wat ik wil vragen en deelnemen aan een feestmaal dat ik voor hem zal bereiden. Morgen zal ik op de vraag van de koning antwoord geven'.

(Est 5:7-8)

Ester is daar om hom seksuele en kulinêre plesier te gee; sy het die hef in die hand: 'Esther is the one who is in confident command: her ingenious play with the two banquets proves that' (Clines 1990:43).

In haar eie interieur waarbinne sy in beheer is en binne die regte sfeer, maak sy tydens die tweede maaltyd bekend dat sy en haar volk uitroeiing in die gesig staar deur die dekreet van 'n bose man. Loader wys hier ook weer op die outeur se meesterlike hantering van die verhullingstegniek as Ester eers die naam van die boosdoener verswyg en op die ironie as Ahasveros uitroep 'Wie is die man, waar is die man die zijn zinnen erop heeft gezet om zoiets te doen?' (7:5). Die leser wat die antwoord ken, moet heimlik glimlag: 'Hier by $u$ aan tafel!' (Loader 1980:105). Ester draai nou nie meer doekies om nie: 'Die meedogenlose vijand, dat is de ellendeling daar, Haman!' (7:6)

Dit lei daartoe dat Haman die galgdood sterf wat hy vir Mordegai beplan het. Mordegai kom in Haman se posisie tereg en verkry vrye toegang tot die koning, omdat Ester hulle verwantskap aan hom bekend gemaak het. Die spanning is verswak, maar nog nie opgelos nie, want die swaard hang nog bo die hoofde van die Joodse volk, want die wet dat hulle vernietig moet word, kan nie herroep word nie. Twee maande verloop sonder dat die besluitlose Ahasveros, met twee Joodse onderdane op die hoogste sport in sy paleishiërargie, ' $n$ vinger verroer om die volk waaraan hulle behoort se lot te verander. Dis nie Mordegai wat vrye toegang het tot Ahasveros wat by hom gaan pleit nie; dis Ester wat voor sy voete neerval, dié keer sonder om die hofseremonie na te kom en huilend pleit vir haar en haar volk se lewe. Ons weet dat Mordegai swyend bystaan en geen woord sê nie, omdat die koning hom in sy antwoord tot Ester én Mordegai rig.

Ahaveros volg weer eens die maklike weg deur die beslissing oor die lot van die Jode op Ester en Mordegai af te skuif. Hy distansieer homself van skuld deur daarop te wys dat hy Haman laat doodmaak het, in der waarheid was die rede daarvoor nie om die Jode te red nie, maar omrede van sy vermeende poging tot aanranding van Ester (Loader 1980:115) en sy besittings aan Ester geskenk het. Nou kan Ester en Mordegai 'n bevelskrif opstel in belang van die Jode en met sy seëlring verseël. Mordegai sorg vir die bewoording van die bevelskrif wat deur berede boodskappers vinnig versprei word: die Jode kry die reg om hulleself te verdedig as hulle volgens Hamman se dekreet op die dertiende dag van die twaalfde maand, Adar, aangeval word. Dit lei tot 'n geweldige slagting waarin die Jode as die oorwinnaars uit die stryd tree.

\section{Besluit: God se ingryping of sy onttrekking}

In sy strukturele lesing wys Loader na aanleiding van Mordegai se opdrag aan Ester om by Ahasveros vir haar volk te gaan pleit daarop dat magsverhoudinge voortdurend in die Ou Testament omgekeer word. Dit gebeur met die afsetting van Vasti as koningin en die verkiesing van Ester as koningin in haar plek. Mordegai se opdrag is niks anders as ' $n$ dreigement met inspeling op die vergeldingsgedagte nie: As Ester faal, sal daar van êrens anders vir die Jode redding kom. Loader (1980:70) verklaar: 'Telkens worden verhoudingen omgekeerd en telkens staat God op het kruispunt als degene die de ommekeer bewerkstelligt.' Hierdie stelling is Loader se uitgesproke oortuiging dat God ingryp op die gebeure aan die Persiese hof. God se naam kom egter nêrens in Ester voor nie en dit weet 'n skerpsinnige leser soos Loader uiteraard. Daarom formuleer hy sy veronderstelde ingryping van God (as die ondergang van Haman in sy stryd teen die Jode en die Jode se oorwinning in die op hande stryd vasstaan) veel versigtiger as die 'religieuse suggestie van een verborgen ordenende macht' (Loader 1980:99).

Loader bly tot in sy slotbeskouinge oor Ester in die hoofstuk 'De boodschap van het verhaal van Esther' konsekwent in sy struktuuranalitiese benadering, ook as hy vashou aan die konnotasie van God se ingryping: 'Er stáát nergens dat God ingrijpt, maar het seculaire verloop is so geschematiseerd dat er een connotatie bijkomt; namelijk de suggestie dat God ingrijpt' ( outeur se kursivering). Loader (1980: 161) heg twee betekenisse aan die 'volk van God': Dit omvat 'degenen die in zijn Zoon geloven, én de gemeenschap van Israël, zelfs 
diegenen daaruit die hun Messias verwerpen.' Die behoud van die Jode in Ester is binne Loader se interpretasie gerig op die toekomstige bekering van die Jode tot Jesus as die Messias. Hierdie interpretasie identifiseer Loader as 'n ideologies-bepaalde leser wie se leesstrategieë hom lei na die ingryping van God op die gebeure in die verhaal as die essensiële betekenis van Ester en vandaar na 'n volkome buitetekstuele religieuse interpretasie van die teks.

Die religieuse dimensie in Ester is egter vaag en vatbaar vir meerdere interpretasie, indien dit enigsins aanwesig is. Sidney Ann White (1989) het volkome gelyk as sy beweer:

As is well known, God is never mentioned in the book of Esther. In addition, the Law and the Covenant are never alluded to; there are no prayers; and Esther, as a Jew, seems to have no scruples abour being married to a Gentile or living in a completely heathen environment.

(White 1989:161)

Nogtans erken sy in ooreenstemming met Loader die verborge religieuse element in Ester wat spreek uit Mordegai se oortuiging dat daar ' $n$ doel agter Ester se verkiesing tot koningin is en dat as sy faal daar van elders redding vir die Jode sal kom. Maar eerder as dat God ingryp, handel Hy deur mense wat Hy toelaat om in die hoofrolle hulle eie heil uit te werk. En White besluit: 'The human element is thus allimportant' (White 1989:162).

Die verhaal van Ester is van aanvang tot slot ' $n$ magspel en 'n magstryd. Die milieu waar die aksie 'n aanvang neem, is die binnehof van die tuin van die paleis wat in 'n indrukwekkende feestoneel omskep is: aan die marmersuile het draperings van wit en purperblou fyn linne aan rooipurper koorde en silwer ringe gehang en op die mosaïekvloer het goue en silwer rusbanke gestaan (1:6). Die funksie van die gedetaileerde beskrywing is nie net om die luister van die fees te beklemtoon nie, maar ook om Ahasveros se vertoonsug bloot te lê. Ironies genoeg word Mordegai 'n deelgenoot in die pronksug van die koning. Die ontvangs van die bevelskrif dat die Jode hulleself mag verdedig lei tot jubeling in Susa en Mordegai verlaat die koning in 'n 'koninklijke gewaad van fijn linnen, blauwpurper en wit van kleur, en hij droeg een grote gouden kroon en een roodpurperen mantel ...' (8:15). Die woordelikse ooreenkoms van die beskrywing van die klere van Mordegai in sy nuwe posisie as vertroueling van die koning met die beskrywing van die versiering van die paleistuin tydens die fees is veelbetekenend. Dit is myns insiens die sterkste motivering van Meir Shalev se ironiese tekening van Mordegai as die 'trotse (Diaspora-) Jood'.

Vir Shalev is Mordegai se weiering om voor Haman te buig sy eerste stap op weg na die posisie van onderkoning binne 'n 'harde politieke strijd zoals ook tegenwoordig voorkomt' en hy besluit:

Zonder enige remming en gespeend van elk joods verantwoordelijkheidsgevoel bleek Mordechai dus bereid het voortbestaan van de hele joodse gemeenschap op het spel te zetten om de hoogste positie aan het Perzische hof in handen te krijgen.

(Shalev 1995:118-119)
Hierdie harde politieke magspel bring 'n wisseling mee tussen wie ingewydes ('insiders') en wie oningewydes ('outsiders') is. Vasti verwyder haarself willens en wetens uit die binnekring waardeur sy haar mag verloor maar haar vroulike waardigheid behou. Deur haar optrede maak sy die hele magspel van mans belaglik as hulle hulle outoritêre gesag oor die vrou laat bevestig deur ' $n$ koninklike dekreet. 'Esther is an outsider who gains power when she becomes an insider' (Clines 1990:39).

Hoe leer ons Ester in haar magsposisie ken? Sy bly binne haar vroulike rol deur oordrewe onderdanigheid teenoor Ahasveros as sy hom nooi na haar maaltye. Dit kom neer op manipulasie wat die uitbuiting van haar skoonheid in 'n seker sin ook is. Wanneer die Jode se selfverdediging op 13 Adar lei tot 'n grootse en magtige oorwinning oor hulle vyande, het Ester die hef in die hand. Sy is nou die magtige Persiese koningin. As Ahasveros haar op hierdie tydstip van die verhaal vra of sy nog 'n wens het, nadat hy reeds al haar versoeke toegestaan het, vra sy dat hy die Jode in die stad Susa weer eens deur 'n koninklike dekreet moet toelaat om ook die volgende dag nog die stryd voort te sit en dat die lyke van Haman se tien seuns aan galge gehang moet word.

Wat het geword van die Joodse meisie Hadassa van wie ons lees dat sy 'lieftallig en mooi' was? 'n Meisie met so 'n warm, menslike hart dat sy selfs die guns van 'n man, geskonde in sy manlikheid, Hegai, die eunug, wat die haremwagter was, se guns kon wen? Of moet ons reeds op hierdie tydstip Ester begin verdink van ambisie en manipulasie? Of moet ons haar eer vir haar versiendheid om te beding vir ' $n$ bestemming as vrou wat ondanks die onaangename aspekte daaraan verbonde vir haar as Jodin verkieslik is bo die kille keersy daarvan? Sy weet immers dat sy haar maagdelikheid gaan verloor in die nag saam met 'n onbesnede koning wat sy nie ken nie en wat as sy hom nie seksueel plesier nie, sy die gevaar loop van eensame verbanning na die tweede vrouehuis.

Ester was op die skaakbord van haar eersugtige, ambisieuse neef Mordegai die pion; letterlik volgens die woordeboekbetekenis die 'skaakstuk van die minste waarde wat, as dit die agterste lyn van die opponent bereik, 'n koningin word'. As Joodse meisie was Ester die mins waarskynlike kandidaat om deur die Persiese koning uit tallose mededingers as koningin gekies te word. Deur haar neef se manipulasie (sy moet verswyg dat sy Joods is) word 'n mooi en onskuldige meisie uit 'n onderdrukte minderheid, 'n harde manipulerende vrou wat nie terugskrik van onnodige bloedvergieting as daar geen sin meer in is nie, omdat die onderdrukkers reeds die neerlaag gely het. Die onderdrukte vrou word die onderdrukkende vorstin.

Die naam van God skitter in sy afwesigheid in die boek Ester. Daaroor sê Shalev (1995):

Misschien is Gods afwezigheid in het boek Esther niets anders dan een subtiele manier waarop de schrijver Gods ongenoegen met de opkomst van de figuur van de diasporajood of de hofjood tot uitdrukking brengt.

(Shalev 1995:120) 
In my lesing kon ek met kommentators saamstem en van hulle verskil. As leser het ek my verset teen die bedoeling van die outeur waartoe 'n struktuuranalitiese benadering jou lei en het ek agter die struktuur by ander bedoelinge probeer uitkom. Wat kan 'n mens sê van die indirekte spreke van God in Ester sonder om dit uit Joodse of Christelike perspektief te interpreteer? Miskien spreek God in Ester deur diegene wat uit die gesigsveld verdwyn, maar agter die teks voelbaar aanwesig bly: Vasti; die eunugs, Bigtan en Teres, en die Joodse meisie Hadassa. Dit is miskien die God van die swakkes, die onaansienlikes en die vernederdes wat Hom in stilswye onttrek aan die politieke spel en intriges van die magtiges.

\section{Literatuurverwysings}

Bellis, A.O., 1994, Helpmates, Harlots and Heroes: Women's stories in the Hebrew Bible, Westminister/John Knox, Louisville, KY.

Clines, D.J.A., 1990, 'Reading Esther from left to right', in D.J.A. Clines, S.E. Fowl \& S.E. Porter (eds.), The Bible in three dimensions, pp. 31-52, Academic Press, Sheffield.

Drennan, I.G., 1992, 'Novelle', in T.T. Cloete (red.), Literêre terme en teorieë, pp. $351-$ 353, HAUM-Literêr, Pretoria.

Klein, L.R., 1995, 'Honor and shame in Esther', in A. Brenner (ed.), The feminist companion to the Bible, pp. 149-175, Academic Press, Sheffield.

Loader, J.A., 1980, Esther, Uitgeverij G.F. Callenbach, Nijkerk.

Nadar, S., 2006, 'Texts of Terror: The conspiracy of rape in the Bible, Church and Society: The case of Esther 2:1-18', in I.A. Phiri \& S. Nadar (eds.), African Women, Religion, and Health, pp. 77-95, Orbis Books, Maryknoll, NY.

Shalev, M., 1995, De bijbel nu, vertl R.Verhasselt, Vassallucci, Amsterdam.

White, S.A., 1989, 'Esther: A feminine model for Jewish Diaspora', in P.L. Day (ed.), Gender and difference in Ancient Israel, pp. 161-177, Fortress Press, Minneapolis, $\mathrm{MN}$. 